\title{
SNPs within CHRNA5-A3-B4 and CYP2A6/B6, nicotine metabolite concentrations and nicotine dependence treatment success in smokers
}

\author{
Jaroslav A. Hubacek', Ivana Kurcova ${ }^{b}$, Vera Maresova ${ }^{b}$, Alexandra Pankova ${ }^{c, d}$, Lenka Stepankovac, Kamila Zvolskac, \\ Vera Lanskae, Eva Kralikova ${ }^{\text {c,d }}$
}

\begin{abstract}
Aim. Plasma values of nicotine and its metabolites are highly variable, and this variability has a strong genetic influence. In our study, we analysed the impact of common polymorphisms associated with smoking on the plasma values of nicotine, nicotine metabolites and their ratios and investigated the potential effect of these polymorphisms and nicotine metabolite ratios on the successful treatment of tobacco dependence.

Methods. Five variants (rs16969968, rs6474412, rs578776, rs4105144 and rs3733829) were genotyped in a group of highly dependent adult smokers $(n=103)$. All smokers underwent intensive treatment for tobacco dependence; 33 smokers were still abstinent at the 12-month follow-up.

Results. The rs4105144 (CYP2A6, $P<0.005)$ and rs3733829 (EGLN2, $P<0.05)$ variants were significantly associated with plasma concentrations of $3 \mathrm{OH}$-cotinine and with $3 \mathrm{OH}$-cotinine: cotinine ratios. Similarly, the unweighted gene score was a significant $(P<0.05)$ predictor of both cotinine:nicotine and $3 \mathrm{OH}$-cotinine:cotinine ratios. No associations between the analysed polymorphisms or nicotine metabolite ratios and nicotine abstinence rate were observed.

Conclusion. Although CYP2A6 and EGLN2 polymorphisms were associated with nicotine metabolism ratios, neither these polymorphisms nor the ratios were associated with abstinence rates.
\end{abstract}

Key words: nicotine-acetylcholine receptors, EGLN2, CYP2A6/B6, tobacco dependence, smoking, cotinine, hydroxycotinine, intensive treatment, nicotine metabolism

Received: August 7, 2019; Revised: October 8, 2019; Accepted: November 14, 2019; Available online: November 29, 2019 https://doi.org/10.5507/bp.2019.058

(c) 2021 The Authors; https://creativecommons.org/licenses/by/4.0/

${ }^{a}$ Centre for Experimental Medicine, Institute for Clinical and Experimental Medicine, Prague, Czech Republic

${ }^{b}$ Department of Toxicology and Forensic Medicine, $1^{\text {st }}$ Faculty of Medicine, Charles University and General University Hospital in Prague, Czech Republic

'Centre for Tobacco-Dependent, $3^{\text {rd }}$ Department of Medicine - Department of Endocrinology and Metabolism, $1^{\text {st }}$ Faculty of Medicine, Charles University and the General University Hospital in Prague, Czech Republic

${ }^{d}$ Institute of Hygiene and Epidemiology, ${ }^{\text {st }}$ Faculty of Medicine, Charles University and the General University Hospital in Prague, Czech Republic

eStatistical Unit, Institute for Clinical and Experimental Medicine, Prague, Czech Republic

Corresponding author: Jaroslav A. Hubacek, e-mail:jahb@ikem.cz

\section{INTRODUCTION}

Nicotine is the agent in tobacco that leads to addiction. After exposure to tobacco smoke, nicotine is quickly metabolised within the body (primarily in the liver) by oxidation to cotinine and further by hydroxylation to trans-3'hydroxycotinine (3OH-cotinine). These metabolites are excreted from the body primarily through urine, but their concentrations are also measurable in blood and saliva and detectable in nails and hair ${ }^{1}$. The half-life of nicotine in the blood is relatively short, that is, approximately $1 \mathrm{~h}$.

Plasma levels of cotinine and nicotine metabolite ratios (NMRs, cotinine:nicotine and 3OH-cotinine:cotinine ratios) are widely used as indicators of phenotypic activity, especially as a measure of CYP2A6 enzyme activity ${ }^{2}$, which is a parameter of nicotine catabolism. These ratios, which measure the rate of nicotine metabolism, have been reported to be associated with the number of cigarettes smoked per day and the likelihood of cessation ${ }^{3}$.
The majority of nicotine within the body (up to $80 \%$ ) is metabolised through cytochrome P4502A6 (CYP2A6) $\left(\right.$ ref. $\left.^{4}\right)$. The CYP2A6 gene is highly polymorphic ${ }^{5}$ and is characterised by extreme interindividual variability; almost 50 variants of the gene have been described to date ${ }^{4,6}$. Common polymorphisms within this gene have been associated with nicotine dependence, age of smoking initiation and daily cigarette consumption ${ }^{7,8}$.

The progress made in identifying the genetic factors that lead to nicotine/tobacco dependence has been achieved largely due to the findings of genome-wide association studies (GWAs). These studies have found that variants within CYP2A6 (rs4105144), CHRNB3/A6 (rs6474412), nicotinic receptor genes (rs16969968 and rs578776) and EGLN2 (rs3733829) are major genetic determinants of dependence ${ }^{7,9}$. The biological importance of some of these variants has also been confirmed in the Czech-Central European Slavic population ${ }^{10}$. 
The aim of our study was to determine whether common polymorphisms associated with nicotine dependence are associated with plasma levels of nicotine metabolites and whether they can be used as predictors (individually or together) for the successful treatment of nicotine dependence.

\section{MATERIALS AND METHODS}

\section{Patient selection and examination}

The study participants were defined according to the WHO's definition as regular smokers who were motivated to stop smoking and were heavy nicotine-dependent (for their general characteristics, see Table 1). The participants presented for treatment of tobacco dependence at the Centre for Tobacco-Dependent Patients ${ }^{11-13}$ in Prague between February 2013 and May 2015.

The baseline visit to this centre, which followed an identical procedure for all subjects, is described in details elsewhere ${ }^{10}$. Briefly, the degree of tobacco dependence (Fagerström Test for Cigarette Dependence [FTCD]) (ref. ${ }^{14,15}$ ) was evaluated, a complete medical history was recorded, and basic physical examinations were performed. Intensive tobacco-dependence treatment procedures consisted of pharmacotherapy and 2-hour psycho-behavioural intervention (www.slzt.cz/intervention-structure) in accordance with Czech and international treatment guidelines ${ }^{13,16}$. Blood was collected for analysis of nicotine metabolites and DNA isolation. The follow-up period was at least 12 months after the first visit. The follow-up visits were performed one or two weeks after inclusion in the study and at 6 months during this time period.

Smoking status after one year of follow-up was verified by measuring carbon monoxide $(\mathrm{CO})$ in expired air with a cut-off $<6$ ppm (Smokerlyzer Micro+ device; Bedfont, Maidstone, Kent, England) according to the Russell Criteria $^{17,18}$.

All study patients provided informed consent. The protocol of the study was approved by the ethics committees of the participating institutes and is in agreement with the Helsinki Declaration of 1975.

\section{DNA analysis}

DNA was isolated from frozen EDTA blood using a standard "salting-out" method" ${ }^{19}$. Three variants (rs16969968, rs6474412 and rs578776) were genotyped using PCR-RFLP, as described in detail previously ${ }^{20}$. The remaining two variants (rs4105144 and rs3733829) were analysed using TaqMan assays (C43815914 and C 2883084 1) on the 7300 Real-Time PCR System ${ }^{10}$. The fact that different methods were used to genotype different SNPs seemed not to be of importance because the different genotyping methods are of a notably similar (and high) accuracy ${ }^{21}$.

\section{Analysis of nicotine metabolites}

An analytical procedure ${ }^{22}$ was modified and validated for the simultaneous identification and quantification of nicotine, cotinine and trans-3'-hydroxycotinine in plasma. Blood for plasma preparation was obtained at a fasting state, approximately 8-12 h after the last cigarette. Solid phase extraction (Bond Elut ${ }^{\circledR}$ Certify SPE Cartridges) and liquid chromatography-tandem mass spectrometry ( $Q$ $\operatorname{Trap}^{\circledR}$ LC-MS/MS 3200 triple quadrupole/linear ion trap mass spectrometer with a TurboIonSpray source (MDS Sciex, Ontario, Canada)) were used. The special chromatography column Restek Allure PFP Propyl 50x2,1 mm, $5 \mu \mathrm{m}$ ID (Cat. No: 9169552) with an appropriate precolumn (Cat. No: 25083) was used. As internal standards for quantification of analytes corresponding deuterated derivatives nicotine- $\mathrm{d}_{3}$, cotinine- $\mathrm{d}_{3}$, 3-hydroxycotinine- $\mathrm{d}_{3}$ were used.

The limit of detection was $2.0 \mathrm{ng} / \mathrm{mL}$ with linearity from 5.0 to $400.0 \mathrm{ng} / \mathrm{mL}$.

Correlation coefficients were greater than 0.99. At two concentrations spanning the linear range of the assay, the intra-assay imprecisions were $<4.0 \%$, while the analytical recovery (bias) was $100.5-103.2 \%$.

\section{Statistical analysis}

Based on the results of individual SNPs, unweighted gene scores were created for 96 subjects; in this case, four polymorphisms were successfully genotyped. Variant rs578776 was excluded from the calculation because it had almost no effect on plasma nicotine or cotinine concentrations. The genotypes associated with the lowest level of nicotine metabolites were scored with 0 points, heterozygotes were scored with 1 point and homozygotes (associated with the highest value of nicotine metabolites) were scored with 2 points. The minimum score value achieved was 0 , while the maximum was 6 . Because there were very small numbers of subjects within the " 0 " $(n=1)$, " 1 " $(n=3)$ and " 6 " $(n=7)$ groups, groups consisting of subjects with $(0+1+2)$ points and $(5+6)$ points were created. ANOVA or the Kruskal-Wallis test were used for statistical analysis. $P$ values at or below 0.05 were considered to be significant.

\section{RESULTS}

A total of 103 patients participated in the study (Table 1). The genotype frequencies of individual SNPs (for more details, see Table 2) corresponded with results obtained from previous studies ${ }^{7,9,23}$.

There was high variability in nicotine and nicotine metabolite concentrations (see Table 1 for means and S.D. values). Importantly, age and sex were not significantly associated with the examined variables (not shown in detail).

Concentrations of $\mathrm{CO}$ at baseline were not significantly associated with treatment success (see Table 1), nor were single polymorphisms or gene score values (data not shown in detail).

There were no significant differences in cotinine:nicotine ratios $(P=0.36)$ for successfully $(n=33,10.9$ $\pm 8.6)$ and unsuccessfully $(n=70,13.2 \pm 14.7)$ treated 
Table 1. General characteristics of examined patients - heavily dependent smokers.

\begin{tabular}{lccc}
\hline Parameter & All patients & Successfully treated & Unsuccessfully treated \\
\hline $\mathrm{n}$ & 103 & 33 & 70 \\
Sex (male/female) & $52 / 51$ & $17 / 16$ & $35 / 35$ \\
Age (years) & $42.7 \pm 13.1$ & $45.8 \pm 14.0$ & $41.5 \pm 12.5$ \\
FTCD & $5.80 \pm 1.82$ & $5.47 \pm 1.84$ & $5.94 \pm 1.82$ \\
Nicotine (ng/mL) & $19.7 \pm 12.8$ & $18.7 \pm 12.1$ & $20.6 \pm 14.7$ \\
CO* $(\mathrm{ppm})$ & $17.2 \pm 9.7$ & $17.8 \pm 8.0$ & $17.1 \pm 10.3$ \\
Cotinine $(\mathrm{ng} / \mathrm{mL})$ & $180 \pm 89$ & $166 \pm 88$ & $186 \pm 95$ \\
3OH-cotinine $(\mathrm{ng} / \mathrm{mL})$ & $115 \pm 85$ & $115 \pm 86$ & $115 \pm 68$ \\
Cotinine:nicotine & $12.4 \pm 12.9$ & $11.0 \pm 8.7$ & $13.0 \pm 14.5$ \\
3OH-cotinine:cotinine & $0.73 \pm 0.61$ & $0.88 \pm 0.84$ & $0.67 \pm 0.37$ \\
\hline
\end{tabular}

All values were obtained before the treatment. No significant differences were detected between successfully and unsuccessfully treated subjects.

Table 2. Plasma concentrations of nicotine metabolites according to the individual genotypes of analysed polymorphisms.

\begin{tabular}{|c|c|c|c|c|}
\hline rs4105144 & $\mathrm{CC}$ & $\mathrm{CT}$ & TT & $P$ \\
\hline $\mathrm{n}$ & 59 & 33 & 11 & \\
\hline Nicotine & $18.9 \pm 11.8$ & $20.7 \pm 14.0$ & $20.9 \pm 16.8$ & 0.91 \\
\hline Cotinine & $171 \pm 76$ & $195 \pm 111$ & $178 \pm 112$ & 0.75 \\
\hline 3OH-cotinine & $126 \pm 91$ & $113 \pm 67$ & $63 \pm 81$ & 0.003 \\
\hline Cotinine:nicotine & $10.9 \pm 6.4$ & $12.2 \pm 10.1$ & $21.4 \pm 33.2$ & 0.91 \\
\hline 3OH-cotinine:cotinine & $0.85 \pm 0.67$ & $0.67 \pm 0.44$ & $0.32 \pm 0.31$ & 0.0005 \\
\hline rs 3733829 & TT & $\mathrm{TC}$ & $\mathrm{CC}$ & $P$ \\
\hline $\mathrm{n}$ & 38 & 48 & 15 & \\
\hline Nicotine & $21.1 \pm 16.9$ & $18.1 \pm 9.8$ & $19.8 \pm 10.9$ & 0.96 \\
\hline Cotinine & $188 \pm 109$ & $166 \pm 83$ & $191 \pm 75$ & 0.47 \\
\hline 3OH-cotinine & $94 \pm 63$ & $124 \pm 101$ & $143 \pm 65$ & 0.03 \\
\hline Cotinine:nicotine & $12.7 \pm 10.6$ & $12.6 \pm 16.1$ & $11.5 \pm 6.6$ & 0.65 \\
\hline 3OH-cotinine:cotinine & $0.60 \pm 0.48$ & $0.82 \pm 0.71$ & $0.84 \pm 0.47$ & 0.02 \\
\hline rs578776 & $\mathrm{CC}$ & $\mathrm{CT}$ & TT & $P$ \\
\hline $\mathrm{n}$ & 67 & 31 & 5 & \\
\hline Nicotine & $19.2 \pm 12.9$ & $20.4 \pm 13.4$ & $22.6 \pm 14.7$ & 0.82 \\
\hline Cotinine & $182 \pm 97$ & $175 \pm 88$ & $176 \pm 65$ & 0.96 \\
\hline 3OH-cotinine & $119 \pm 95$ & $107 \pm 58$ & $116 \pm 88$ & 1.00 \\
\hline Cotinine:nicotine & $10.5 \pm 7.7$ & $10.3 \pm 6.1$ & $13.5 \pm 15.3$ & 0.48 \\
\hline 3OH-cotinine:cotinine & $0.63 \pm 0.34$ & $0.74 \pm 0.67$ & $0.74 \pm 0.59$ & 0.99 \\
\hline rs6474412 & TT & $\mathrm{TC}$ & $\mathrm{CC}$ & $\mathrm{P}$ \\
\hline $\mathrm{n}$ & 60 & 35 & 6 & \\
\hline Nicotine & $20.0 \pm 13.0$ & $19.9 \pm 12.2$ & $20.6 \pm 18.4$ & 0.98 \\
\hline Cotinine & $188 \pm 100$ & $177 \pm 80$ & $138 \pm 69$ & 0.36 \\
\hline 3OH-cotinine & $114 \pm 75$ & $127 \pm 102$ & $67 \pm 42$ & 0.21 \\
\hline Cotinine:nicotine & $11.2 \pm 6.9$ & $12.2 \pm 10.5$ & $24.7 \pm 42.5$ & 0.77 \\
\hline 30H-cotinine:cotinine & $0.72 \pm 0.56$ & $0.80 \pm 0.72$ & $0.48 \pm 0.24$ & 0.33 \\
\hline rs 16969968 & GG & GA & AA & $P$ \\
\hline $\mathrm{n}$ & 41 & 42 & 20 & \\
\hline Nicotine & $19.5 \pm 12.8$ & $21.4 \pm 13.5$ & $16.5 \pm 12.4$ & 0.44 \\
\hline Cotinine & $169 \pm 84$ & $197 \pm 99$ & $164 \pm 94$ & 0.32 \\
\hline 3OH-cotinine & $107 \pm 62$ & $108 \pm 72$ & $149 \pm 133$ & 0.74 \\
\hline Cotinine:nicotine & $10.3 \pm 5.8$ & $13.9 \pm 17.0$ & $13.6 \pm 13.4$ & 0.55 \\
\hline 3OH-cotinine:cotinine & $0.75 \pm 0.67$ & $0.63 \pm 0.45$ & $0.92 \pm 0.72$ & 0.11 \\
\hline
\end{tabular}


Table 3. Association between gene score (created from the rs4105144, rs3733829, rs6474412 and rs 16969968 polymorphisms) and nicotine metabolite ratios.

\begin{tabular}{cccc}
\hline Gene score & $\mathrm{n}$ & Cotinine:nicotine & 3OH-cotinine:cotinine \\
\hline $0-2$ & 9 & $24.0 \pm 34.4$ & $0.41 \pm 0.31$ \\
3 & 20 & $11.2 \pm 6.5$ & $0.51 \pm 0.29$ \\
4 & 17 & $10.9 \pm 12.4$ & $0.83 \pm 0.59$ \\
$5-6$ & 50 & $11.5 \pm 6.8$ & $0.86 \pm 0.71$ \\
\hline$P$ & & 0.05 & 0.005 \\
\hline
\end{tabular}

The $P$ value is calculated to determine trends.

smokers and no significant $(P=0.51)$ differences in $3 \mathrm{OH}-$ cotinine:cotinine ratios for successfully $(0.88 \pm 0.82)$ and unsuccessfully $(0.67 \pm 0.37)$ treated smokers.

The individual SNPs that impacted the plasma values of the studied parameters are summarised in Table 2.

In agreement with previous observations, the strongest effect on plasma values of nicotine metabolites was observed in the case of the rs 4105114 polymorphism within the surroundings of the CYP2A6 gene $(P<0.0005$ for $3 \mathrm{OH}-$ cotinine:cotinine ratio). The second strongest individual SNP to have a significant effect on nicotine metabolism values was the rs 3733829 polymorphism (EGLN2 gene; $P<0.02$ ). The other three analysed polymorphisms had no significant effect on nicotine metabolite values or on nicotine metabolite ratios.

Gene score values had no effect on the plasma levels of individual metabolites but were significantly (Table 3; $P<0.05$ and 0.005 , respectively) associated with NMRs.

We did not observe any association between plasma levels of nicotine metabolites or their ratios and 12-month abstinence rates, even though the FTCD values were slightly lower in successfully treated patients (Table 1).

Finally, polymorphisms were not associated with 12-month abstinence rates (data not shown in detail).

\section{DISCUSSION}

Cotinine, the predominant metabolite of nicotine, is widely used as a marker of nicotine intake ${ }^{1}$.

In our study, we confirmed that genetic variability plays an important role in determining the plasma levels of nicotine metabolites. However, we were unable to confirm an association between plasma levels of nicotine metabolites or nicotine metabolite ratios and successful tobacco dependence treatment (smoking cessation). This effect may have been attributable to the small sample size.

The interesting finding of our study is the association between the rs 3733829 tagging variant within the EGLN2 (egl-9 hypoxia-inducible factor 2) gene and plasma levels of cotinine. This finding is of particular interest because it is the only variant that was not confirmed as a significant predictor of smoking dependence in our previous study, in which only a borderline $(P=0.07)$ association was detected ${ }^{10}$. However, this finding does correspond with the results of recent GWAs (ref. ${ }^{24}$ ), which have also detected SNPs within EGLN2 as markers of nicotine metabolism.
The most significant determinant of NMR in our study was the rs4105144 polymorphism within the CYP2A6/CYP2B6 loci. This result is in agreement with the current consensus on the role of this locus in nicotine metabolism ${ }^{25}$. The CYP2A6 pathway is directly involved in tobacco addiction because it converts up to $80 \%$ of nicotine ${ }^{26}$; therefore, it is not surprising that the genetic variability within these nicotine-metabolising enzymes is considered the most significant predictor of nicotine metabolite concentrations and NMRs (ref. ${ }^{27}$ ). The rs 4105144 polymorphism is in almost complete linkage disequilibrium with enzyme null alleles ${ }^{7}$ (rs 1801572 polymorphism). Nucleotide exchange regulates CYP2A6 expression and is localised within the putative binding site for the glucocorticoid receptor transcription factor ${ }^{28}$.

Interestingly, Bloom et al. ${ }^{29}$ suggested that although the abovementioned SNPs within the EGLN2 and CYP2A6 loci are both mentioned as a proxy of CYP2A6 functionality, if analysed together, EGLN2 is not an independent marker of nicotine metabolism. Unfortunately, our study has insufficient power (a relatively low number of subjects are included) to analyse all possible combinations of alleles.

Several large studies have focused on the association between cotinine levels and genetic variability. In agreement with the European Prospective Investigation into Cancer and Nutrition (EPIC) study ${ }^{27}$, we confirmed an association between the rs4105144 variant and measurements of nicotine metabolism. However, in our study, this association was expressed as a relation between SNP and $3 \mathrm{OH}-$ cotinine but not cotinine itself.

An interesting discrepancy between the EPIC study and ours relates to rs 16969968 . Although this variant localised within the cluster of A5-A3-B4 nicotinic receptors is the strongest determinant of smoking dependence ${ }^{27,30,31}$ and is significantly associated with cotinine levels in a large sample of 12500 subjects from six pooled studies $^{32}$, we confirmed the association in Czech smokers with smoking dependence ${ }^{10}$; however, we observed only minor trends in terms of the effect of this SNP on nicotine metabolites or their ratios. In a study by Falcone et al., ${ }^{3}$ although no connection was observed between this SNP and NMR, an association was reported for the number of cigarettes smoked per day. This finding confirms that the mechanism by which this variant influences smoking dependence is independent of nicotine metabolism.

The remaining two variants (rs578776 within the cluster of nicotinic receptors and rs6474412 in the vicinity 
of $C H R N 3 B / A 6)$ did not significantly influence smoking cessation success or plasma values of nicotine metabolites or NMRs.

Offsetting the strengths of our study (ethnic homogeneity of the patients, homogeneous group of dependent smokers, supervised intensive treatment, long follow-up time) are its limitations. The abovementioned criteria did not allow us to assemble a large group of patients or to compare abstainers and cessation failures in detail; as a result, the statistical power of our study is relatively low. Furthermore, there is considerable variability within the $C Y P 2 A 6$ gene. We analysed only one SNP within this gene, and although GWAs show that it is the most significant predictor of smoking behaviour, there are no data on subjects with loss-of-function alleles in our study. Finally, we did not analyse concomitant medication, which could have interacted with nicotine metabolism (drugs metabolised through the CYP2A6 pathway).

The large range of plasma nicotine metabolite concentrations observed in our study, as well as in the abovementioned studies in successfully and unsuccessfully treated dependent patients, suggests that the potential of NMRs to predict treatment success is questionable. Due to the large span of values, data could be significant at the population level but weakly predictive at individual levels. As such, NMRs are unlikely to be used as a future key predictor in personalised medicine $\mathrm{s}^{33,34}$.

Although NMRs are widely suggested as potential markers of nicotine dependence, their real relation to nicotine dependence seems to be minor ${ }^{5,1}$, especially because of their large interindividual variability. This variability is observed because other factors can also partly influence NMR values, such as genetic and dietary differences, as well as age, sex and the use of some medications ${ }^{1}$.

\section{CONCLUSION}

Circulating levels of nicotine metabolites are unlikely to be strong predictors for the successful treatment of nicotine dependence in individual cases.

Acknowledgements: Supported by Ministry of Health Czech Republic - conceptual development of research organisation ("Institute for Clinical and Experimental Medicine - IKEM, IN 00023001”) and by the Charles University project PROGRES 025/LF1.

Author contributions: JAH: study design, genetic analyses, manuscript writing; IK: nicotine metabolite analysis, manuscript editing; VM: nicotine metabolite analysis, manuscript editing; AP: data collection, manuscript editing; LS: data collection, manuscript editing; KZ: data collection, manuscript editing; VL: statistical analysis, manuscript editing; EK: study design, data collection, manuscript editing.

Conflict of interest: None declared.

\section{REFERENCES}

1. Benowitz NL, Hukkanen J, Jacob P 3rd. Nicotine chemistry, metabolism, kinetics and biomarkers. Handb Exp Pharmacol 2009;(192):2960.

2. Ray R, Tyndale RF, Lerman C. Nicotine dependence pharmacogenetics: role of genetic variation in nicotine-metabolizing enzymes. J Neurogenet 2009;23(3):252-61.

3. Falcone $M$, Jepson C, Benowitz N, Bergen AW, Pinto A, Wileyto EP, Baldwin D, Tyndale RF, Lerman C, Ray R. Association of the nicotine metabolite ratio and CHRNA5/CHRNA3 polymorphisms with smoking rate among treatment-seeking smokers. Nicotine Tob Res 2011;13(6):498-503.

4. López-Flores LA, Pérez-Rubio G, Falfán-Valencia R. Distribution of polymorphic variants of CYP2A6 and their involvement in nicotine addiction. EXCLI J 2017; 16:174-96.

5. Tricker AR. Nicotine metabolism, human drug metabolism polymorphisms, and smoking behaviour. Toxicology 2003;183(1-3):151-73.

6. Raunio H, Rahnasto-Rilla M. CYP2A6: genetics, structure, regulation, and function. Drug Metabol Drug Interact 2012;27(2):73-88.

7. Thorgeirsson TE, Gudbjartsson DF, Surakka I, Vink JM, Amin N, Geller F, Sulem P, Rafnar T, Esko T, Walter S, Gieger C, Rawal R, Mangino M, Prokopenko I, Mägi R, Keskitalo K, Gudjonsdottir IH, Gretarsdottir $\mathrm{S}$, Stefansson $\mathrm{H}$, Thompson JR, Aulchenko YS, Nelis M, Aben KK, den Heijer M, Dirksen A, Ashraf H, Soranzo N, Valdes AM, Steves C, Uitterlinden AG, Hofman A, Tönjes A, Kovacs P, Hottenga JJ, Willemsen G, Vogelzangs N, Döring A, Dahmen N, Nitz B, Pergadia ML, Saez B, De Diego V, Lezcano V, Garcia-Prats MD, Ripatti S, Perola M, Kettunen J, Hartikainen AL, Pouta A, Laitinen J, Isohanni M, HueiYi S, Allen M, Krestyaninova M, Hall AS, Jones GT, van Rij AM, Mueller T, Dieplinger B, Haltmayer M, Jonsson S, Matthiasson SE, Oskarsson $\mathrm{H}$, Tyrfingsson T, Kiemeney LA, Mayordomo Jl, Lindholt JS, Pedersen $\mathrm{JH}$, Franklin WA, Wolf $\mathrm{H}$, Montgomery GW, Heath AC, Martin NG, Madden PA, Giegling I, Rujescu D, Järvelin MR, Salomaa V, Stumvoll M, Spector TD, Wichmann HE, Metspalu A, Samani NJ, Penninx BW, Oostra BA, Boomsma DI, Tiemeier H, van Duijn CM, Kaprio J, Gulcher JR; ENGAGE Consortium, McCarthy MI, Peltonen L, Thorsteinsdottir $\mathrm{U}$, Stefansson K. Sequence variants at CHRNB3-CHRNA6 and CYP2A6 affect smoking behaviour. Nat Genet 2010;42(5):448-53.

8. Pan L, Yang X, Li S, Jia C. Association of CYP2A6 gene polymorphisms with cigarette consumption: a meta-analysis. Drug Alcohol Depend 2015;149:268-71.

9. Tobacco and Genetics Consortium. Genome-wide meta-analyses identify multiple loci associated with smoking behaviour. Nat Genet 2010;42(5):441-7.

10. Hubacek JA, Pankova A, Stepankova L, Zvolska K, Adamkova V, Lanska V, Kralikova E. SNPs within CHRNA5-A3-B4 and CYP2A6/B6 are associated with smoking dependence but not with tobacco dependence treatment outcomes in the Czech population. Gene 2017;606:35-8.

11. Králíková $E$, Kmetová $A$, Štěpánková $L$, Zvolská $K$, Felbrová V, Kulovaná S, Bortlicek Z, Blaha M, Fraser K. Tobacco dependence, the most important cardiovascular risk factor: treatment in the Czech Republic. Physiol Res 2014;63 Suppl 3:S361-8.

12. Kmetova A, Kralikova E, Stepankova L, Zvolska K, Blaha M, Sticha M, Bortlicek Z, Schroeder DR, Croqham IT. Factors associated with weight changes in successful quitters participating in a smoking cessation program. Addict Behav 2014;39(1):239-45.

13. Králíková E, Češka R, Pánková A, Štěpánková L, Zvolská K, Felbrová V, Kulovaná S, Zvolský M. [Tobacco dependence treatment guidelines]. Vnitr Lek 2015;61Suppl1:4-15. (In Czech)

14. Heatherton F, Kozlowski LT, Frecker RC, Fagerström KO. The Fagerström test for nicotine dependence: A revision of the Fagerström Tolerance Questionnaire. British J Addictions 1991;86(9):1119-27.

15. Fagerström K. Determinants of tobacco use and renaming the FTND to the Fagerström Test for Cigarette Dependence. Nicotine Tob Res 2012;14(1):75-8.

16. Fiore MC, Jaén CR, Baker TB, Bailey WC, Benowitz NL, Curry SJ, Dorfman SF, Froelicher ES, Goldstein MG, Healton CG, Henderson PN, Heyman RB, Koh HK, Kottke TE, Lando HA, Mecklenburg RE, Mermelstein RJ, Mullen PD, Orleans CT, Robinson L, Stitzer ML, Tommasello AC, Villejo L, Wewers ME, Murray EW, Bennett G, 
Heishman S, Husten C, Morgan G, Williams C, Christiansen BA, Piper ME, Hasselblad V, Fraser D, Theobald W, Connell M, Leitzke C. Treating Tobacco Use and Dependence: 2008 Update. Clinical Practice Guideline. Rockville, MD: U.S. Department of Health and Human Services. Public Health Service. 2008; May.

17. West R, Hajek P, Stead L, Stapleton J. Outcome criteria in smoking cessation trials: proposal for a common standard. Addiction 2005;100(3):299-303.

18. West $\mathrm{O}$, Hajek P, McRobbie H. Systematic review of the relationship between the 3-hydroxycotinine/cotinine ratio and cigarette dependence. Psychopharmacology (Berl) 2011;218(2):313-22.

19. Miller SA, Dykes DD, Polesky HF: A simple salting out procedure for DNA extraction from human nucleated cells. Nucleic Acid Res 1988;16(3):1215.

20. Hubacek JA, Lanska V, Adamkova V. Lack of an association between SNPs within the cholinergic receptor genes and smoking behavior in a Czech post-MONICA study. Genet Mol Biol 2014;37(4):625-30.

21. Hubáček JA, Pikhart $H$, Peasey A, Kubínová R, Bobák M. Nobody is perfect: comparison of the accuracy of PCR-RFLP and KASP ${ }^{\mathrm{TM}}$ method for genotyping. ADH1B and FTO polymorphisms as examples. Folia Biol (Praha) 2015;61(4):156-60.

22. Shakleya DM, Huestis MA. Simultaneous and sensitive measurement of nicotine, cotinine, trans-3'-hydroxycotinine and norcotinine in human plasma by liquid chromatography-tandem mass spectrometry. J Chromatogr B Analyt Technol Biomed Life Sci 2009;877(29):353742.

23. Hubacek JA. Drug metabolising enzyme polymorphisms in Middleand Eastern-European Slavic populations. Drug Metabol Drug Interact 2014;29(1):29-36.

24. Loukola A, Buchwald J, Gupta R, Palviainen T, Hällfors J, Tikkanen E, Korhonen T, Ollikainen M, Sarin AP, Ripatti S, Lehtimäki T, Raitakari $\mathrm{O}$, Salomaa V, Rose RJ, Tyndale RF, Kaprio J. A genome-wide association study of a biomarker of nicotine metabolism. PLoS Genet 2015;11(9):e1005498.

25. Salloum NC, Buchalter ELF, Chanani S, Espejo G, Ismail MS, Laine RO, Nageeb M, Srivastava AB, Trapp N, Trillo L, Vance E, Wenzinger M, Hartz SM, David SP, Chen LS. From genes to treatments: a systematic review of the pharmacogenetics in smoking cessation. Pharmacogenomics 2018;19(10):861-71.

26. Malaiyandi V, Sellers EM, Tyndale RF. Implications of CYP2A6 genetic variation for smoking behaviors and nicotine dependence. Clin Pharmacol Ther 2005;77(3):145-58.

27. Timofeeva MN, McKay JD, Smith GD, Johansson M, Byrnes GB Chabrier A, Relton C, Ueland PM, Vollset SE, Midttun $\varnothing$, Nygård O, Slimani N, Romieu I, Clavel-Chapelon F, Boutron-Ruault MC, Fagherazzi G, Kaaks R, Teucher B, Boeing H, Weikert C, Bueno-de-
Mesquita HB, van Gils C, Peeters PH, Agudo A, Barricarte A, Huerta JM, Rodríguez L, Sánchez MJ, Larrañaga N, Khaw KT, Wareham N, Allen NE, Travis RC, Gallo V, Norat T, Krogh V, Masala G, Panico S, Sacerdote C, Tumino R, Trichopoulou A, Lagiou P, Trichopoulos D, Rasmuson T, Hallmans G, Riboli E, Vineis P, Brennan P. Genetic polymorphisms in $15 q 25$ and $19 q 13$ loci, cotinine levels, and risk of lung cancer in EPIC. Cancer Epidemiol Biomarkers Prev 2011;20(10):225061.

28. Schuit E, Panagiotou OA, Munafò MR, Bennett DA, Bergen AW, David SP. Pharmacotherapy for smoking cessation: effects by subgroup defined by genetically informed biomarkers. Cochrane Database Syst Rev 2017;9:CD011823.

29. Bloom AJ, Baker TB, Chen LS, Breslau N, Hatsukami D, Bierut LJ, Goate A. Variants in two adjacent genes, EGLN2 and CYP2A6, influence smoking behavior related to disease risk via different mechanisms. Hum Mol Genet 2014;23(2):555-61.

30. Saccone NL, Wang JC, Breslau N, Johnson EO, Hatsukami D, Saccone SF, Grucza RA, Sun L, Duan W, Budde J, Culverhouse RC, Fox L, Hinrichs AL, Steinbach JH, Wu M, Rice JP, Goate AM, Bierut LJ. The CHRNA5-CHRNA3-CHRNB4 nicotinic receptor subunit gene cluster affects risk for nicotine dependence in African-Americans and in European-Americans. Cancer Res 2009;69(17):6848-56.

31. Ware JJ, Chen X, Vink J, Loukola A, Minica C, Pool R, Milaneschi Y, Mangino M, Menni C, Chen J, Peterson RE, Auro K, Lyytikäinen LP, Wedenoja J, Stiby Al, Hemani G, Willemsen G, Hottenga JJ, Korhonen T, Heliövaara M, Perola M, Rose RJ, Paternoster L, Timpson N, Wassenaar CA, Zhu AZ, Davey Smith G, Raitakari OT, Lehtimäki $T$, Kähönen M, Koskinen S, Spector T, Penninx BW, Salomaa V, Boomsma DI, Tyndale RF, Kaprio J, Munafò MR. Genome-wide metaanalysis of cotinine levels in cigarette smokers identifies locus at 4q13.2. Sci Rep 2016;6:20092.

32. Munafò MR, Timofeeva MN, Morris RW, Prieto-Merino D, Sattar N Brennan $P$, Johnstone EC, Relton C, Johnson PC, Walther D, Whincup PH, Casas JP, Uhl GR, Vineis P, Padmanabhan S, Jefferis BJ, Amuzu A, Riboli E, Upton MN, Aveyard P, Ebrahim S, Hingorani AD, Watt G, Palmer TM, Timpson NJ; EPIC Study Group, Davey Smith G. Association between genetic variants on chromosome 15q25 locus and objective measures of tobacco exposure. J Natl Cancer Inst 2012;104(10):740-8.

33. Maroñas O, Latorre A, Dopazo J, Pirmohamed M, RodríguezAntona C, Siest G, Carracedo Á, LLerena A. Progres in pharmacogenetics: consortiums and new strategies. Drug Metab Pers Ther 2016;31(1):47-54

34. Rodríguez Vicente AE, Herrero Cervera MJ, Bernal ML, Rojas L, Peiró AM. Personalized medicine into health national services: barriers and potentialities. Drug Metab Pers Ther 2018;33:159-63. 